\title{
ACCESS TO JUSTICE AND FAIR FOR THE POOR: HOW EFFECTIVE THE LEGAL AID PROVIDED BY GOVERNMENT?
}

\author{
Dani Setiawan* \\ Justice and Fair Community, Denpasar, Indonesia \\ *Email: danistwn10@gmail.com
}

\begin{abstract}
Providing legal assistance to the poor continues by the government to realize legal access and justice for all levels of society. Several regulations regarding legal aid have been issued by the state through the law and implementing regulations, but the fact is that the provision of legal aid is not yet effective. This causes a lack of access to law and justice for the poor. The effectiveness of providing legal aid by the government needs to be assessed to see how effective the legal aid program provided by the government is to realize legal access and justice for the poor. Therefore, criticism and advice should be given to the government in order to optimize legal assistance in order to achieve legal access and justice for all levels of society.
\end{abstract}

Keywords: Access to Justice; Poor People; Legal Aid; Government

The Indonesian Journal of International Clinical Legal Education DOI: https://doi.org/10.15294/ijicle.v3i2.46173

Submitted: Nov 11, 2020 Revised: Jan 30, 2021 Accepted: Feb 22, 2021 Available online at https://journal.unnes.ac.id/sju/index.php/iccle

(C) 2021 Authors. This work is licensed under a Creative Commons AttributionShareAlike 4.0 International License (CC BY-SA 4.0). All writings published in this journal are personal views of the authors and do not represent the views of this journal and the author's affiliated institutions. 


\section{INTRODUCTION}

The protection of the human rights of every individual or citizen is an obligation for a country that establishes itself as a state of law. Indonesia as a state of law in carrying out law enforcement recognizes the principle of equality before the law (equality before the law). This principle has been embodied in the provisions of Article 27 paragraph (1) of the 1945 Constitution which reads "All citizens are equal before the law and the government are obliged to uphold the law and the government with no exceptions". As a consequence of the recognition of this principle, all have the right to be treated equally before the law without exception.

Equality before the lawrequires equality before the law. The poor as one part of the citizens of course also have the right to be guaranteed their rights, including when facing legal problems. Moreover, Indonesia's constitution in Article 34 (1) of the 1945 Constitution states that the poor and neglected children are looked after by the state. The phrase "maintained" is not just providing the need for food and clothing, but also the need for access to law and justice. law and justice. ${ }^{2}$ So based on this, access to law and justice must be realized for the poor who are facing legal problems.

The government in its efforts to realize access to law and justice for the poor has issued Law Number 16 of 2011 concerning Legal Aid. The law states that law enforcers, especially advocates, are required to provide free legal aid for the poor in Indonesia. The obligation to provide legal assistance by advocates as a normative consequence for advocates as officium nobile (noble profession) and has been mandated in Law Number 18 of 2003 concerning Advocates. ${ }^{3}$ In addition, as a manifestation of the government's role in providing legal aid to the poor, the government annually provides funds to organizations providing legal aid. For the 2019-2021 period, the Government has budgeted a legal aid fund of 53 billion to be given to legal aid organizations. Seeing the amount of funds provided by the government, of course, we also need to look at whether the provision of legal aid by the government has been effective and can realize access to law and justice for the poor. Based on this, the author would like to review the effectiveness of the provision of

1 Sri Rahayu Wilujeng, "Hak Asasi Manusia: Tinjauan dari Aspek Historis dan Yuridis", Jurnal Humanika, Vol. 18 No. 2 Edisi Juli-Desember 2013, Fakultas Ilmu Budaya UNDIP: Semarang, p. 162.

2 Deborah L. Rhode, Access to Justice, Oxford University Press : New York, 2004, pp. 3-5.

3 Frans Hendra Winarta, 2009, Pro Bono Publico, Hak Konstitusional Fakir Miskin untuk Memperoleh Bantuan Hukum, Gramedia : Jakarta, pp. 1-2, see also Frans Hendra Winarta, 2011, Bantuan Hukum di Indonesia, Hak untuk Didampingi Penasihat Hukum Bagi Semua Warga Negara, Elex Media Komputindo : Jakarta, p. 101 
legal aid provided by the government in realizing access to law and justice for the poor. Based on this background, the formulation of the problem was found as follows:

1. What form of legal aid is provided to the poor?

2. How is the development of providing legal aid to the poor?

3. How effective is the provision of legal aid provided by the government in realizing access to law and justice for the poor?

The type of research carried out is normative juridical, namely research carried out based on the main legal material by examining theories, concepts, legal principles, and laws and regulations related to this research. ${ }^{4}$ While the data analysis was carried out through a qualitative approach, namely the existing data were connected, compared, and described in words and/or sentences. In addition, the method of thinking used in this paper is a method of deductive thinking, namely a pattern of thinking that is based on things that are general in nature and then described with things that are specific. ${ }^{5}$

Sources of data used in the form of secondary data as the main data and primary data as supporting data. Secondary legal materials in the form of legal opinions and theories obtained from books, journals, bulletins, research results, and so on. Meanwhile, primary legal materials are obtained through the relevant laws and regulations.

\section{FORMS OF LEGAL AID PROVIDED TO THE POOR}

According to Frans Hendra Winarta, legal aid is a special legal service provided to the poor who need a free defense, both outside and inside the court, in criminal, civil and state administration, from someone who understands the ins and outs of legal defense, principles and rules of law, as well as human rights. ${ }^{6}$ Another understanding, according to Adnan Buyung Nasution, is legal aid specifically for legal aid for low-income groups or in poor popular language, the measure of poverty is still a difficult problem to solve, not only for developing countries but even for developing countries. even advanced ones are still a problem. ${ }^{7}$

4 Soekanto, S, Mamudji, S, Penelitian Hukum Normatif (Suatu Tinjauan Singkat), Jakarta: Rajawali Pres, 2001, p. 7

5 Izhar. 2016. "Mengidentifikasi Cara Berpikir Deduktif dan Induktif dalam Teks Bacaan Melalui Pengetahuan Koteks dan Referensi Pragmatik". Jurnal Pesona. Volume 2, p.68.

6 Frans Hendra Winarta, Bantuan Hukum Suatu Hak Asasi Manusia Bukan Belas Kasihan, Elex Media Komputindo : Jakarta, 2000, p. 23.

7 Adnan Buyung Nasution, Bantuan Hukum di Indonesia, Bantuan Hukum dan Politik Pembangunan, LP3ES: Jakarta, 2007, p. 10-15. 


\section{Dani Setiawan}

Legal aid itself has four concepts in its application. The concepts are as follows:

1. The concept of traditional legal aid is that legal services are provided to the poor individually, are passive, and the approach is very formal-legal.

2. The concept of constitutional legal aid is legal aid for the poor which is carried out within the framework of broader efforts and objectives, such as: awareness of the rights of the poor as legal subjects, enforcement and development of human rights values as the main pillar of upholding the rule of law. ${ }^{8}$

3. The concept of structural legal aid is an activity that aims to create conditions for the realization of a law that is able to change an unequal structure towards a more just structural one, where legal regulations and their implementation can guarantee equality of position both in the legal and political fields. The concept of structural legal aid is closely related to structural poverty. ${ }^{9}$

4. The concept of responsive legal aid is legal aid that is given to the poor free of charge and covers all areas of law and human rights and does not differentiate between individual and collective defense cases. The services provided in responsive legal assistance are in the form of legal counseling on human rights and the legal process for the right to be defended by legal aid organizations and or advocates, defense in overcoming concrete legal problems, quality defense in courts in order to produce a more firm and clear jurisprudence, and right of the several legal aid concepts that can be applied to help realize access to law and justice for the poor, the concept of legal aid is responsive and structural. ${ }^{10}$

In an effort to realize access to law and justice for the poor, the government has issued Law Number 16 of 2011 concerning Legal Aid. Legal aid as contained in Article 4 paragraph (2) of Law Number 16 of 2011 concerning Legal Aid is provided in a scope that includes civil, criminal, and state administrative matters, both litigation and nonlitigation. The forms of legal assistance provided under the provisions of Article 4 paragraph (3) of Law Number 16 of 2011 concerning Legal Aid include exercising power, assisting, representing, defending, and/or taking other legal actions for the legal interests of the Legal Aid Recipients.

The government's contribution in realizing access to law and justice for the poor is also made by providing funds to legal aid organizations.

8 YLBHI, 2014, Panduan Bantuan Hukum di Indonesia, Yayasan Obor Indonesia: Jakarta, p. 462

9 Suradji, 2008, Etika dan Penegakan Kode Etik Profesi Hukum (Advokat), Badan Pembinaan Hukum Nasional Departemen Hukum dan HAM RI: Jakarta, p. 77.

10 Frans Hendra Winata, 2009, Probono Publico, Hak Konstitusional Fakir Miskin Untuk Memeperoleh Bantuan Hukum, PT. Gramedia Pustaka Utama, Jakarta, p.12. 
Where the handling of cases on a free basis is funded by the government. In the Circular Letter of the Supreme Court (SEMA) Number 10 of 2010 concerning Legal Aid (currently it has been revoked by the Regulation of the Supreme Court of the Republic of Indonesia Number 1 of 2014 concerning Guidelines for Providing Legal Services for Poor People in Courts) it is stated that what is meant by prodeo is a litigation process. in court for free with state funding through the budget of the Supreme Court of the Republic of Indonesia. Then regarding the funding of legal aid, it is also stated in Article 16 paragraph (1) of Law Number 16 of 2011 concerning Legal Aid which states that the Legal Aid Funding required and used for the implementation of Legal Aid in accordance with this Law is charged to the Revenue and Expenditure Budget. Country. Based on this description, it is clear how the government's role in realizing legal aid to the poor is to ensure access to law and justice for all parties without exception.

\section{THE DEVELOPMENT OF PROVIDING LEGAL AID TO THE POOR}

The development of legal aid in Indonesia continues to increase. For the 2019-2021 period, the Government has budgeted a legal aid fund of 53 billion to be given to legal aid organizations. The amount of funds provided by the government is solely for the purpose of realizing access to law and justice for all levels of society. Then based on data from the National Legal Development Agency, it shows that the total applications for legal aid that came in in 2016 reached 5,592 cases and Non-Litigation cases were 1,103 cases so that the total amounted to 6,695 cases. Of this number, 3,335 cases were accepted and 797 cases were rejected, if the total number of cases reached 4,132 cases. ${ }^{11}$ Based on this, it means that there are about 2563 cases that have been lost or even ignored, moreover this is data that is inputted nationally to the center, meaning it is not impossible that there are some cases that are not inputted or there is no awareness for the poor to ask for legal assistance even though they are are in trouble with the law. Public awareness of legal aid or access to law and justice tends to be apprehensive, based on data from a study which states that legal knowledge in Indonesia is still low. A national quantitative study has shown that $56 \%$ of the community cannot show an example of the rights they have. This figure increased dramatically for women $(66 \%)$ and for respondents with no formal education $(97 \%) .{ }^{12}$

11 Irma Tambunan, "Bantuan Hukum Gratis Bagi Kaum Miskin", Kompas, 16 January 2017.

12 Supra, Kerangka Kerja untuk Penguatan Akses Hukum dan Keadilan di Indonesia, Justice for the Poor Project The World Bank, Jakarta, pp. 6-10. 


\section{Dani Setiawan}

The implementation of the provision of legal aid in the community also has an irregularity that causes access to law and justice for the poor to have not been achieved. Some of the problems that hinder legal aid for the poor are as follows: ${ }^{13}$

1. The Normative Legal Framework for the Provision of NonWorking Legal Aid

Quoting from the opinion of Satjipto Rahardjo "Laws that were created and have never been implemented have essentially ceased to be laws"14 26 The normative legal framework regarding the provision of legal aid at the level of practice in the community, especially for the constituents of the regulation, namely the poor are still not carried out optimally by advocates as one of the legal aid providers.

There are three things the behavior of advocates in dealing with the problem of assistance for the poor, namely avoiding for various reasons, accepting the case on the condition that the case must attract the mass media so that it raises the prestige of the advocate, and finally fully accepting the provision of legal aid. ${ }^{15}$ Some advocates prefer to defend middle and upper class clients rather than poor people, this can reduce the advocate profession as a noble profession into a commercial profession.

2. Lack of Legal Awareness in the Poor

Ignorance of the law will result in someone breaking the law or someone being fooled by an individual to take advantage, and what is more surprising is that the person is usually from law enforcement or the government. ${ }^{16}$ To quote John Rawls, "all legal systems will fail if they are not encouraged by a genuine personal moral attitude (justice as farness) in society." 17 Based on this opinion, if it is clashed with the application of legal aid for the poor, if the poor in practice still lack legal awareness and legal knowledge of the importance of legal aid, then the provision of legal aid will not function optimally.

The perspective of the application of providing legal aid for the poor is not only seen as meeting the community's need for

13 Suyogi Imam, "Optimalisasi Pemberian Bantuan Hukum Demi terwujudnya Acces to Law and Justice Bagi Rakyat Miskin". Jurnal Konstitusi No. 1 tahun 2018, Fakultas Hukum Unsoed: Purwokerto, pp. 10-12.

14 Satjipto Rahardjo, "Hukum dan Perubahan Sosial", Genta Publishing, Yogyakarta, 2009, p. 69.

15 Marudut Tampubolon, Membedah Profesi Advokat, Perspektif Ilmu Sosial Interaksi Advokat-Klien, Pustaka Pelajar: Yogyakarta, 2014, pp. 133-134.

16 Muhadi Zainuddin, "Peran Sosialisasi UU Advokat dalam Pemberdayaan Kesadaran Hukum Masyarakat”. Jurnal Al-Mawarid No. 12 Tahun 2004, Fakultas Ilmu Agama UII : Yogyakarta, p 93.

17 Theo Huijbers, FIlsafat Hukum dalam Linstas Sejarah, Kanisius, Yogyakarta, 2013, pp. 193-202 
assistance in every legal process, but more than that, namely making the community understand the law and be able to criticize existing legal products, namely by providing legal and citizenship education for the community (civic education). ${ }^{18}$ This perspective can ideally solve this problem, but it is not yet appropriate at the level of implementation. Based on the results of the research conducted, it was found that several lawyers and legal aid institutions still tend to view the provision of legal aid as passive. The perspective of providing passive legal aid can become a parasite that can reduce the optimization of legal aid provision. Perspectives here can be illustrated such as, the provision of legal assistance provided by advocates/LBH upon the appointment of the police or court as legal advisors due to the provision of funds from the court and cases whose punishment is above 15 years in prison as recommended by the Criminal Procedure Code. ${ }^{19}$

Based on Perma No. 1 of 2014 concerning Guidelines for Providing Legal Services for Underprivileged Communities in Courts, court institutions provide a budget to provide free legal aid and establish a Legal Aid Post (Posbakum). ${ }^{20}$ The presence of access to legal aid is not without problems, the problem that arises is the 'limitation of the budget provided, so that if the allotted budget has been absorbed then there are cases of poor people who need free legal aid or the case needs to be brought to the court of appeal, cassation or reconsideration can be simply ignored, because the budget provided has been completely absorbed. This will raise the next problem. ${ }^{21}$ Based on the perspective that the provision of legal aid is passive and the limited access provided by the court will reduce the optimization of the provision of legal aid for the poor. This makes the urgency of the sensitivity of advocates/LBH to view the provision of legal aid actively and not rely too much on the access provided by the court.

18 Binziad Kadafi, Advokat Indonesia Mencari Legitimasi: Studi Tentang Tanggung Jawab Profesi Hukum di Indonesia. Pusat Studi Hukum dan Kebijakan Hukum: Jakarta, 2001, p. 182

19 Kelompok Kerja Paralegal Indonesia, 2014, Kritisi Rancangan UUBH dari Aspek Paralegal dan Pemberdayaan Hukum (Legal Empowerment), KKPI : Jakarta, p. 15. See also Pujiarto, I. W., Kalo, S., \& Ikhsan, E. (2016). Pelaksanaan Pemberi Bantuan Hukum Dikaitkan dengan Undang-undang No. 16 Tahun 2011 Tentang Bantuan Hukum. Arena Hukum, 8(3), 318-341.

20 Andry Rahman Arif, "Pelaksanaan Pemberian Bantuan Hukum Terhadap Terdakwa Yang Tidak Mampu Dalam Perkara Pidana Di Kota Bandar Lampung”, Jurnal Fiat Justitia, Vol. 9 No. 1 Edisi Januari-Maret 2015, p 106.

21 Isnandar Syahputra Nasution, "Urgensi Peran Pengadilan dalam Memberikan Pelayanan Bantuan Hukum Terhadap Orang Miskin Sesuai Undang- Undang No.16 Tahun 2011 Tentang Bantuan Hukum", Jurnal Hukum dan Peradilan, Vol. 4 No. 1 Edisi Maret 2015, p. 185. 


\section{Dani Setiawan}

3. Access to Justice is Only a Formality

Errors in the application of law and legal subjects (error in persona) carried out by judges as controllers of the court process is not a rare thing in judicial practice in Indonesia, this is what is called a misguided trial. ${ }^{22}$ Often in practice in the community, especially the poor people experience/become victims of a deviant judiciary, although there is access to an appeal, cassation or judicial review to avoid a misguided trial, it is not possible for the poor to use this access because it will cost the poor a lot of money to be paid.

Based on this, the existence of the Legal Aid Law is not a guarantee for the poor to get access to appeal, cassation or review. This is because at the level of practice in society, the application of legal aid is only a formality by some advocates and LBH. Based on the results of the research conducted,41 some of the provision of legal aid is carried out to the courts of the first instance. From the point of view of an advocate/LBH, this is done at the request of the client (the poor), but from the point of view of the poor the request (no appeal, cassation, review) is based on submission and does not have the cost to access it.

4. Discrimination and Complicated Procedures in Funding Legal Aid

The Law on Legal Aid provides funding for advocates/LBH with a variety of complicated requirements and procedures. The conditions given are more likely to be fulfilled by LBH alone, and even then there must be a selection process commonly referred to as accreditation as legitimacy to absorb the legal aid funding, this has the tendency of discrimination.

Based on the results of verification and accreditation in 2013, there were only 310 organizations that passed. ${ }^{23}$ This figure is very small, so there are still LBHs that do not pass accreditation, especially in the areas of Papua, Bali, NTT, NTB. ${ }^{24}$ Not to mention that the procedure for absorbing these funds is very complicated, because the funding is delegated to the Ministry of Law and Human Rights whose legal position (office area) only exists in each province. This means that $\mathrm{LBH}$ domiciled in cities far from the

22 Rahmat Efendy Al Amin Siregar, "Studi Tentang Peradilan Sesat (Rechterlijke Dwaling) Dan Hubungannya Dengan Memudarnya Kepercayaan Masyarakat Terhadap Hukum", Jurnal FITRAH, Vol. 8 No. 1 Edisi Januari-Juli Tahun 2014, p. 22.

23 The Indonesia Legal Resource, 2013, Kajian Awal Hasil Verifikasi dan Akreditasi Organisasi Bantuan Hukum, Jakarta.

24 Ispurwandoko Susiolo, "Pendidikan Hukum Klinik (Clinic Legal Education) dalam Pelaksanaan UU No. 16 Tahun 2011 Tentang Bantuan Hukum”, Jurnal Hukum dan Masyarakat, Vol. 13 No. 2 Edisi April 2014, p. 22 
province will find it difficult to access these funds. ${ }^{25}$ Based on the conditions, the process of accreditation and absorption of funds is complicated and tends to be discriminatory, which can result in the absorption of legal aid funds nationally being ineffective. This tends to cause many advocates/LBH to collect other fees in providing legal aid.

5. There is no supervision in the application of legal aid.

Supervision is the most important thing to keep from overstepping or abusing. Negligence for legislators, especially the Legal Aid Law, normatively does not accommodate the provisions of Supervision in the application of legal aid. Supervision in the application of legal aid plays an important role in maintaining the balance of legal aid relations according to their designation. Loose supervision can open a loophole to misappropriate state money (corruption) or to sacrifice hopes for its realization.access to law and justice for the poor. ${ }^{26}$

\section{THE EFFECTIVENESS OF LEGAL AID PROVIDED BY THE GOVERNMENT IN REALIZING ACCESS TO LAW AND JUSTICE FOR THE POOR}

Based on the above discussion and if it is associated with several research results and available data, a conclusion is found to explain the effectiveness of providing legal aid by the government in realizing access to law and justice for the community, namely as follows:

1. Government funding to assist legal aid organizations has not been optimally absorbed by all legal aid organizations in all regions in Indonesia as a result of the existence of criteria and verification from the government of legal aid organizations. So this causes there are still some areas that have poor people who cannot get access to the law if they are caught in legal problems.

2. The provision of legal aid is not supported by the government's legal aid education program for the poor. This has caused some poor people to still be reluctant to use legal aid services from legal aid organizations because of their ignorance of the legal process.

25 Gabriel Betsyeba, 2013, "Pelaksanaan Bantuan Hukum Cuma-Cuma Yang Diberikan Oleh Advokat Kepada Masyarakat Yang Kurang Mampu", Artikel Ilmiah, Fakultas Hukum UAJY: Yogyakarta, pp. 12-13.

26 Muhammad Rustamaji, "Menakar Pengawasan Pemberian Bantuan Hukum Dalam Pandangan Richard A Posner, Jurnal Rechtsvinding, Vol. 2 No. 1 Edisi April 2013, pp. 100-103. 


\section{Dani Setiawan}

3. With the government's many shortcomings in its efforts to provide legal assistance, this has resulted in uneven access to law and justice for the poor in Indonesia.

\section{CONCLUSION}

Based on the discussion and description above, the following conclusions were found:

1. The form of legal assistance provided by the government to the poor is realized by the existence of Law Number 16 of 2011 concerning Legal Aid. The government provides funding in the form of APBN and APBD to support legal aid organizations in providing legal aid services to the poor.

2. The development of the provision of legal aid by the government to the poor continues to increase. This can be seen from the nominal funds provided by the government to legal aid organizations to help the poor who are caught in legal problems, but in practice the provision of legal aid is still not optimal, this is caused by several things, namely: the normative legal framework for providing legal aid that does not work, lack of legal awareness among the poor, access to justice is only a formality, discrimination and complicated procedures in the funding of legal aid, and the absence of supervision in the application of legal aid.

3. The provision of legal aid by the government has not been effective, this is due to the unequal funding of legal aid organizations and the absence of legal aid education to the poor. This causes the provision of legal aid by the government has not been able to realize access to law and justice for the poor in Indonesia.

\section{SUGGESTION}

Based on the problems that have been described to realize the effectiveness of legal aid and realize access to law and justice for the poor, the authors have several opinions as follows:

1. The government should evaluate the funding program for legal aid organizations in Indonesia. In this case, the government must prioritize the distribution of funding to all regions in Indonesia.

2. The government is expected to create legal aid education programs for the poor so that public legal awareness increases and legal aid programs can run optimally.

3. The community is expected to assist government programs in educating all levels of society about legal aid. 


\section{REFERENCES}

Arif, A. R. (2015). Pelaksanaan Pemberian Bantuan Hukum Terhadap Terdakwa Yang Tidak Mampu Dalam Perkara Pidana Di Kota Bandar Lampung. Fiat Justisia: Jurnal Ilmu Hukum, 9(1).

Bethsyeba, G. (2013). Pelaksanaan Bantuan Hukum Cuma-Cuma Yang Diberikan Oleh Advokat Kepada Masyarakat Yang Kurang Mampu. Jurnal Ilmu Hukum, 1-17.

Fauzi, S. I., \& Ningtyas, I. P. (2018). Optimalisasi pemberian bantuan hukum demi terwujudnya access to law and justice bagi rakyat miskin. Jurnal Konstitusi, 15(1), 50-72.

Huijbers, T. (2013). Filsafat Hukum dalam Linstas Sejarah. Yogyakarta: Kanisius.

Kadafi, K. (2001). Advokat Indonesia Mencari Legitimasi: Studi Tentang Tanggung Jawab Profesi Hukum di Indonesia. Jakarta: Pusat Studi Hukum dan Kebijakan Hukum.

Kelompok Kerja Paralegal Indonesia. (2014). Kritisi Rancangan UUBH dari Aspek Paralegal dan Pemberdayaan Hukum (Legal Empowerment). Jakarta: KKPI.

Nasution, A. B. (2007). Bantuan Hukum di Indonesia, Bantuan Hukum dan Politik Pembangunan. Jakarta: LP3ES.

Nasution, I. S. (2015). Urgensi Peran Pengadilan dalam Memberikan Pelayanan Bantuan Hukum terhadap Orang Miskin Sesuai Undang-Undang Nomor 16 Tahun 2011 tentang Bantuan Hukum. Jurnal Hukum dan Peradilan, 4(1), 171-188.

Pujiarto, I. W., Kalo, S., \& Ikhsan, E. (2016). Pelaksanaan Pemberi Bantuan Hukum Dikaitkan dengan Undang-undang No. 16 Tahun 2011 Tentang Bantuan Hukum. Arena Hukum, 8(3), 318-341.

Rahardjo, S. (2009). Hukum dan Perubahan Sosial. Yogyakarta: Genta Publishing.

Rhode, D. L. (2004). Access to Justice. New York: Oxford University Press.

Rustamaji, M. (2013). Menakar pengawasan pemberian bantuan hukum dalam pandangan Richard A Posner. Jurnal Rechts Vinding: Media Pembinaan Hukum Nasional, 2(1), 95-106.

Siregar, R. E. A. A. (2014). Studi Tentang Peradilan Sesat (rechterlijke dwaling) dan hubungannya dengan memudarnya kepercayaan masyarakat terhadap hukum. Jurnal FITRAH, 8(1), 17-30.

Soekanto, S., \& Mamudji, S. (2001). Penelitian Hukum Normatif (Suatu Tinjauan Singkat). Jakarta: Rajawali Pres.

Supra, S. (2010). Kerangka Kerja untuk Penguatan Akses Hukum dan Keadilan di Indonesia. Jakarta: Justice for the Poor Project The World Bank. 


\section{Dani Setiawan}

Suradji, S. (2008). Etika dan Penegakan Kode Etik Profesi Hukum (Advokat). Jakarta: Badan Pembinaan Hukum Nasional Departemen Hukum dan HAM RI.

Susiolo, I. (2014). Pendidikan Hukum Klinik (Clinic Legal Education) dalam Pelaksanaan UU No. 16 Tahun 2011 Tentang Bantuan Hukum. Jurnal Hukum dan Masyarakat, 13(2), 1-26.

Tambunan, I. (2017). "Bantuan Hukum Gratis Bagi Kaum Miskin", dalam Kompas, 16 January 2017.

Tampubolon, M. (2014). Membedah Profesi Advokat, Perspektif Ilmu Sosial Interaksi Advokat-Klien. Yogyakarta: Pustaka Pelajar.

The Indonesia Legal Resource Center. (2013). Kajian Awal Hasil Verifikasi dan Akreditasi Organisasi Bantuan Hukum. Jakarta: ILRC.

Wilujeng, S. R. (2013). Hak Asasi Manusia: Tinjauan dari aspek historis dan yuridis. Humanika, 18(2).

Winarta, F. H. (2000). Bantuan Hukum Suatu Hak Asasi Manusia Bukan Belas Kasihan. Jakarta: Elex Media Komputindo.

Winata, F. H. (2009). Probono Publico, Hak Konstitusional Fakir Miskin Untuk Memperoleh Bantuan Hukum. Jakarta: PT. Gramedia Pustaka Utama.

YLBHI. (2014). Panduan Bantuan Hukum di Indonesia. Jakarta: Yayasan Obor Indonesia.

Zainuddin, M. (2004). Peran Sosialisasi UU Advokat dalam Pemberdayaan Kesadaran Hukum Masyarakat. Al-Mawarid Journal of Islamic Law, 12(11), 26019.

\section{Conflicting Interest Statement}

All authors declared that there is no potential conflict of interest on publishing this article.

\section{Funding}

None

\section{Publishing Ethical and Originality Statement}

All authors declared that this work is original and has never been published in any form and in any media, nor is it under consideration for publication in any journal, and all sources cited in this work refer to the basic standards of scientific citation.

Cite this article as:

Setiawan, D. (2021). Access to Justice and Fair for the Poor: How Effective the Legal Aid Provided by Government?. The Indonesian Journal of International Clinical Legal Education, 3(2), 173-184. https://doi.org/10.15294/ijicle.v3i2.46173 